\title{
Good enough fathering Om identitetsbildning hos skilsmässofäder och deras barn
}

\section{LARS-ERIK BERG}

\section{I artikeln presenteras resultat frän en svensk studie med 25 fränskilda fäder och deras barn. Resultaten visar en annan bild än de stereotypa och negativa fadersbilder som vi ibland möter $i$ den allmänna debatten och $i$ vissa studier.}

\section{Inledning och teoretisk bakgrund}

Kan skilsmässofadern lära oss något om hưr den gode fadern är eller bör vara? Ytligt sett borde han inte det, eftersom han just är skilsmässofader; en god far överger inte sina barn genom att skilja sig från deras mor. Men så enkelt är det ju inte. Just genom att dessa fäder hamnat i svårigheter med att träffa sina barn har de möjlighet att bearbeta fadersrollen både praktiskt och teoretiskt. Detta ska vi studera, men först en teoretisk bakgrund för att peka på den diskurs som den moderna fadersdiskussionen växt fram ur.

Ellen Key utnämnde 1900-talet till barnens århundrade. Hon fick rätt åtminstone i så måtto att barn- och utvecklingspsykologin startade en revolutionerande utveckling. Något senare började också föräldraskapet att problematiseras. Detta kom så småningom att innebära att föräldrar bör-

Lars-Erik Berg, docent, sociologiska institutionen vid Göteborgs universitet, också verksam vid Högskolan i Skövde. jadebetrakta sin föräldragärning med reflekterande och kritiska ögon. En del forskare menar att detta inneburit att föräldraauktoriteten på ett generellt sätt har gröpts ur (t.ex. Lasch 1977 och 1979). Lasch befinner sig i den lite paradoxala situationen att han kritiserar utifrån en ortodox freudsk synvinkel, medan man kan säga om just psykoanalysen att dess populariserade former $\mathrm{i}$ stor utsträckning bidragit till föräldrauktoritetens urholkning. Ofta är det just psykoanalytiker från olika läger som fått beskriva hur den goda föräldern ska se ut. Därigenom har de verksamt bidragit till den "socialpatologiserande» process som Lasch kritiserar.

Mödraskapet var tidigast med att bli rannsakat och kritiserat, troligen av det enkla skälet att modern ända fram till för några decennier sedan var den förälder som självklart var hemma och tog hand om barnen. Ofta har det lagts samman med versioner av feminismen (t.ex. Chodorow 1978), och resultatet har blivit en livaktig emancipatorisk kvinnoforskning. Från 70-talet har denna också vänt sig mot sådana 
tidiga kritiker av mödraskapet som Benjamin Spock och René Spitz (båda verksamma på 50-talet). I Sverige skulle 50-talets radiodoktor Bertil Söderling kunna tjäna som en måltavla för feministisk kvinno- och mödraforskning (Blomqvist 2001). 80-talets Hans H Gustavsson ändrade på detta och lät mamman komma ut $\mathrm{i}$ arbetslivet och fadern hem till familjen. Familjedemokratin släpps in och familjen blir en i bästa fall vänlig ochkärleksfull förhandlingsgrupp. Förhandlingen stimulerar ett allt intensivare diskuterande och reflekterande.

Objektrelationsteorin kan sägas vara en brobyggare som haft viktiga konsekvenser för den ovan nämnda familje-vetenskapliga och -politiska diskursen. Den innefattar en socialpsykologisering av psykoanalysen. Författare som Klein, Fairbairn och Winnicott fäste mer upnmärksamhet vid harnets drift att relatera till andra människor än vid dess libidinösa drift, som Freud hade gjort. Kanske kan man säga att de fäste sig mera vid den psykosociala kärleksdriften än vid driften till behovstillfredsställelse.

Winnicott myntade begreppet "Good enough Mothering". Han syftade på barnets önskan om en oändligt älskande och accepterande mor, på hennes oförmåga att tillmötesgå det omnipotent krävande barnet på denna punkt och på att det finns en gräns, långt under vad barnet kräver, som ändå är tillräcklig för att barnet ska kunna utvecklas på ett gott sätt. En "Good enough Mother» duger som en mycket god moder, utan att vara tillräcklig för barnets omedelbara önskningar. Bland annat visar hon barnet genom sina naturliga restriktioner på ett gott sätt att världen inte är gränslös.

Begreppetär välkänt och associationsrikt för beteendevetare i skilda läger. Hos Winnicottär det fortfarande modern som är den centrala figuren i familjen för barnen. Faderskapet har hamnat i rampljuset först senare. Enligt Johansson (2001) har den manliga identiteten börjat diskuteras allvarligt och grundligt först med 80-talet, och faderns identitet och sociala konstruktion är ett ännu nyare forskningsfält, frånsett enstaka pionjärer som Joseph Pleck.

Det är få som kan fylla ett begrepp som "Good enough Fathering" med substantiellt innehåll, trots att det goda fadrandet allså började studeras systematiskt för 20 år sedan (Lamb, i Lamb [ed.] 1997). Detta intresse har emellertid odlats inom en speciell sektor, nämligen studiet av och rädslan för vad som händer med barnensfadersidentifikation i skilsmässofamiljer. Det är alltså s.a.s. en "aversiv stimulusus som ligger bakom fadersstudiet. Motsvarande gäller inte på samma sätt för det mera globala begreppet om "Good enough mothering".

Fadrandet ses ofta från den negativa sidan, som frånvaron av en "Good enough Father". Denna frånvaro kan blåsas upp till enorma proportioner. Lyssna till president Clinton: „The single biggest social problem in our society may be the growing absence of fathers from their children's homes because it contributes to so many other social problemsu. ${ }^{1}$ De olika slags problem och lidanden som anses kunna uppträda för i första hand barnen, när fadern är frånvarande är

1 Fost 1996, citerad från Lupton and Barclay 1997 s 2. Även Susan Faludi 2001 hänvisar till Clintons starka uttalanden om fadersfrånvaro i dagens USA. Hennes bok utgör en generell vidräkning med den underminering av den manliga identiteten som skett sedan 2:a världskriget. 
det speciella skälet för det s.a.s. "riktade» intressset för den gode fadern. Barnen kan få en blandad och diffus bild av faderskap och maskulinitet, och detta gör det svårt för söner att utveckla egen könsidentitet på ett harmoniskt vis. Resultatet blir stereotypa uppfattningar och praxis gällande båda könen. Detta kan bereda väg för dålig anpassning mellan könen, och i botten av detta problemkomplex finner vi pojkar i grupp våldta flickor, begå andra våldshandlingar, rån och t.o.m. mord på oskyldiga människor i svaga positioner, som barn och gamla. Svenska massmedia har uppmärksammat en sådan bild, men det är inte ett fenomen som är begränsat till vårt land (se Lupton o Barclay 1997 s 78 ff). I kärnan av intresset för fadersrollen finns en sådan typ av dramer.

Men få har försökt precisera vad det positiva innehållet skulle kunna vara $\mathrm{i}$ ett begreppsom Goodenough Fathering 2 . Ändå är det också så att åtmistone under den tid som samhällsvetenskapen visat ett systematiskt intresse för fadern, så har det internationellt iakttagits att fäder $\mathrm{i}$ allt större utsträckning visar intresse för sina barn på ett konkret deltagande plan (Pleck in Lamb [ed.] 1997 p 67). För att tala med Charlotte Hagströms ord: Många män som är fäder blir också pappor (Hagström 1999), nämligen under en socio-emotionell process efter barnets födelse. Sådana rapporter börjar komma på sistone (t.ex. Plantin 2001, Berg och Chronholm 2001).

2 Inom psykoanalysen, och även annorstädes, finns det undantag. Freud själv och senare Lacan har skissat på innehållet i den goda fadersgestalten.
Finns det då en motsättning mellan å ena sidan ett generellt ökande intresse och deltagande från fäder, och å andra sidan en möjlig ökning av en del barns dåliga anpassning, t.ex. ökad och/eller råare aggressivitet? Sådant relateras ofta till fadersfrånvaro och ökande skilsmässor. Givetvis kan det vara så att den statistiska fördelningens båda extremändar ökar medan mitten blir tunnare: samtidigt som fler fäder engagerar sig i barnen (en positiva änden i fördelningen) blir också fler barn socialt faderslösa genom skilsmässa eller på annat sätt (den negativa änden). Men motsättningen är skenbar. Utvecklingen är snarare förbunden med modernitetens senare stadier i en generell bemärkelse (Giddens 1990, 1991 och 1992). Skilsmässoproblematiken är en delaspekt av en mycket bredare förändringsprocess.

Det finns en "infernalisk" aspekt i denna utveckling. Men att bara se ett inferno gör oss lätt blinda. Det finns något annat att se också. Utöver att ett ökande antal fäder i kärnfamiljer engagerar sig mer finns det mycket som tyder pả att många frånskilda fäder utvecklar ett starkt engagemang i sina barn, och att de gör det delvis just pga att de har en egen ansvarsrelation till barnen. Likaså är det så att en del av de "dåliga» fädernahelt enkelt intehar möjlighet att göra sig gällande i sin önskan att ta hand om sina barn. Inte heller detta är ett endast nordiskt eller svenskt fenomen. Lamb (ed. 1997), Fürstenberg och Cherlin (1991), McLanahan och Sandefur (1994) och andra redovisar en mängd material av liknande slag för USA.s vidkommande, och Lewis och O'Brien (1987) liksom Burgess (1997) tar upp saken från engelsk synvinkel. Båda län- 
derna dras med stora problem kring skilsmässor och frånvarande fäder, men engagerade frånskilda fäder tycks också vara många.

\section{Studiens inriktning och uppläggning}

Min text koncentreras nu på att presentera vissa resultat från en svensk studie kring frånskilda fäder och deras barn (Berg och Johansson 1999).

Det material jag använder kommer från en studie baserad på samtalsartade intervjuer med ca 25 frånskilda fäder och deras barn och behandlar de båda parternas identitetsutveckling sett utifrån skilsmässoperspektivet. ${ }^{3}$ Intervjuerna innehåller också frågor och svar som har relevans för inte bara

3 Fäderna intervjuades två gånger med minst ett års intervall. Barnen intervjuades vid det senare tillfället. Mycket få barn under 6 år intervjuades, och de gav i allmänhet ett magert material; intervjuer med små barn kräver bl.a. en tidsbudget som vi inte förfogade över. Några av barnintervjuerna från tidig skolålder gav oss fint material men det viktigaste materialet har utan tvivel tonårsbarnen samt ett fåtal nyligen vuxna gett oss. Några av dessa har gett oss långa sammanhängande berättelser med stor tyngd. Vi har förstås haft problem med att de (nästan) vuxna barnen inte berättar direkta upplevelser utan drar fram minnen från en förfluten barndom. Vi anser att vi ändå har fått mycket mer av dessa äldre barn med en gammal skilsmässa än vi skulle ha kunnat få av små barn. Studien genomfördes av mig och min medarbetare Thomas Johansson, och den finansierades av HSFR. Många resultat har redovisats i boken "Den andre föräldern" (Carlssons förlag 1999), men min artikel använder annat material som inte är focuserat i boken. upplevelsen av den verklige fadern och hans maskulinitet utan också, från båda parter, föreställningar om hur "Den gode fadern" kan se ut och vara. Detta material extraherar och renodlar jag och låter det utgöra stommen i min framställning.

I några få fall har fäderna gemensam vårdnad med modern, men de flesta har "gett ifrån sig vårdnaden", som några uttrycker saken, till förmån för ett gott umgängesavtal. ${ }^{4}$ De allra flesta har mer umgänge med barnen än vad som går in under beteckningen "söndagspappa». Mönster som varannan torsdag kväll till måndag morgon är vanliga, liksom varannan fredag kväll till måndag morgon plus varje onsdag. Trots moderns vårdnadförekommer umgänge som närmar sig hälften - hälften. I de flesta fall har fadern lämnat familjens hem och modern stannat med harnen. Detta mönster tycks inte vara blott och bart historia.

Jag ska koncentrera mig på den »lyckliga» delen av materialet utan att för den skull förneka att det finns eländesbeskrivningar att hämta också. Mitt syfte är just att beskriva hur skilsmässopappan kan komma att bli den gode fadern; därför mest om de lyckliga fallen.

\section{Skilsmässan som katastrof eller möjlighet; barnens syn}

I synnerhet den anglosaxiska litteraturen kring skilsmässor nästan drivhusodlar synen på skilsmässan och den frånvarande fadern

4 Denna punkt är mindre aktuell idag, då lagstiftningen förändrats så att det normala är gemensam/delad vårdnad. 
som en mänsklig katastrof. Orsakerna är ekonomiska, sociala och emotionella. ${ }^{5}$ Det är emellertid möjligt att vända ögonen och se från andra hållet, att studera skilsmässan mera som ett försök till lösning av dåliga förhållanden i familjen. På det viset behöver den inte ses som en förstörelse av mänskliga resurser, som t.ex. McLanahan and Sandefur (1994) explicit gör. Bilden av den frånvarande skilsmässopappan bör kompletteras med bilden av den skilsmässopappa som är desto mer engagerad när han träffar sina barn. Denna syn ska hjälpa mig undersöka vad som händer i interaktionen mellan far och barn.

Det är inte vi som forskare som anlade detta synsätt. Vi var bundna av samhällsvetenskaplig tradition och hade katastrofsynen ingrodd i vår inlästa förhandsuppfattning. (Det kan förstås ses som en form av intervjuar-bias.) Det var främst barnen som tvingade oss att öppna ögonen för de lyckliga aspekterna av skilsmässa.

Just barnen, i högre grad än fäderna, har ett enkelt och rationellt sätt att betrakta frågan på. De störs inte av moraliserande argument. De säger: Om föräldrar inte kan ge stöd och hjälp åt varandra och utöva kärlek längre, då ska de som en helt naturlig sak skilja sig. Det finns inget konstigt med detta! Och när vi direkt frågar dem om de legala aspekterna kring skilsmässan, så ser de processen som en självklar mänsklig rätttighet. Dessa unga moralfilosofer kan över huvud taget inte föreställa sig att juridiken på något sätt skulle utöva makt över män-

5 Några exempel på denna »eländestendens«i den engelska och amerikanska litteraturen är Fürstenberg och Cherlin (1991) och en redan klassisk studie av Wallerstein and Kelly (1980). niskors önskan att skilja sig, (eller för den delen inte skilja sig).

Men denna mycket raka och odramatiska attityd betyder ingalunda att de ser skilsmässa som en bagatell. En del av dem ger oss berättelser om sorg, ilska och dov vrede, när vi frågar efter deras känslor vid skilsmässan. Med andra ord: De tränger knappast bort så mycket av problemen. Mönstret är att de dåliga känslorna förläggs till en ganska kort och intensiv period. Det finns också ett svagt könsmönster. Inga pojkar ger uttryck för intensiva känslor, varken nu eller vid det aktuella tillfället, så som de kommer ihåg det. Flickor är mer känsliga. Men i hela materialet är det bara en flicka som släpper lös direkta känslor; hon gråter en smula vid berättelsen. Då är det ändå en mycket dramatisk skilsmässa med svåra konflikter och blockeringar, som hon berättar om.

Vi tror inte att vi fătt hela spektret av känslor i detta. En del dåliga känslor har blivit omedvetet bortträngda, och några har rationellt blivit »bortresonerade«. ${ }^{6}$ Ändå finns det något att lära. Dessa barn har tvingat oss att ifrågasätta doktriner som hävdar att barnens sunda utveckling nödvändigtvis kräver båda föräldrarnas kontinuerliga närvaro i familjen. En del sådana synsätt finns invävda i den nämnda litteraturen. Vårt material bekräftar inte detta. Och det bekräftar heller inte synen på den fränskilde fadern som den frånvarande fadern. Vi tror att en del forskning tenderar att blanda samman tre faktorer som är analytiskt åtskilda, nämligen skilsmässa,

6 Många rapporter om detta finns dels teoretiskt i psykoanalytisk litteratur, dels empiriskt i kliniskt/terapeutiska rapporter. 
den fysiskt frånvarande fadern och dåliga sociala/känslomässiga förhällanden.

Vi har en tentativ förklaring till sammanblandningen. Vi finner en tydlig skillnad mellan den "typiskau svenska skilsmässan och den engelska eller amerikanska motsvarigheten. De senare försiggår i en kultur som stigmatiserar skilsmässan på annat vis än som tycks ske i Sverige. Ett exempel från Fürstenberg/Cherlin(1991).Den amerikanska skilsmässan försiggår i ett klimat där föräldrarna berättar om skilsmässan först när den faktiskt börjar äga rum, och då berättar de så lite som möjligt för att "skona» barnen. Det är också klart att det ekonomiska samhällsstödet till ensamstående föräldrar är svagare i USA än i Sverige.

Ivårt material är motsatsen till detta ofta sann: Barnen får i typfallet höra och delta i berättelser och diskussioner på ett tidigt stadium, i den mån de är gamla nog att förstå alls. Orsakerna till skilsmässan läggs öppet fram. Barnen får veta, att när pappa flyttar, så kommer de att träffa honom helt regelbundet. Slutligen får barnen höra tydligt framlagt att de själva inte har någon orsak till skilsmässan utan att det är något som gäller bara mellan föräldrarna. Några av "våra barn har blivit vuxna vid intervjutillfället, och de visar en varm erkänsla för sina föräldrar för dessas förmåga att under dramatiska omständigheter ha sinnesnärvaro att berätta så klart och nyktert för sina barn.

Det är ett tydligt faktum i vårt material att barnen själva inte betraktar skilsmässan och de ibland korta mötena med fadern som absoluta hinder för ett ngood enough fatheringu. Vad kan då växa fram ur denna speciella sorts relation, så vanlig numera? Jag ska ge två typer av svar på denna fråga. Den första typen kommer ur fädernas och barnens föreställningar om vad som kan genereras ur skilsmässan som sådan, alltså hur förälder - barn-relationen förändras av själva skilsmässan som ett s.a.s. strukturellt faktum. Den andra svarstypen i materialet skisserar "den gode fadern", så som han ser ut för våra två kategorier av intervjupersoner. Jag ställer upp materialet efter denna princip. Framställningen domineras av sökandet efter positiva snarare än negativa attityder. Den goda skilsmässan och den gode fadern fokuseras, och båda kategorierna kommer tilll tals under dessa underrubriker.

Variabeln barn/fäder kommer alltså i framställningen nedan underordnas på det sättet att både barn och fäder kommer till tals under båda huvudrubrikerna, A och B.

\section{A: \\ Den goda skilsmässan som levnadsvillkor}

\section{A1: Problematisering, reflexion och klokhet}

Redan en ytlig titt bereder väg för tanken att skilsmässan tvingar både fäder och barn till reflexion och problemlösning. Det finns indikationer på flera håll om att fadern blir mer uppmärksam mot barnen och mer ifrågasättandeochkreativ gällande relationsproblem i familjegruppen, inklusive modern. Reflexion kring familjeproblem blir en kontinuerlig verksamhet, som ofta får en intensiv karaktär. Dessa fäder blir "familjeforskare"; de fokuserar och utkristalliserar den väv av problem som omger deras liv med 
barnen. Vissa forskar hävdar att reflexionen blir mer mogen hos fäder och barn som gått igenom skilsmässans svårigheter (Lund 1987, Giddens 1991 and 1992, Bauman 1991): Problemen hamnar hela tiden i rampljuset och kräver sin lösning. ${ }^{7}$ Att bearbeta relationsproblem blir en del av vardagen och det egna identitetsprojektet.

Denna tendens är mycket tydlig $\mathrm{i}$ vårt material. Vissa fäder blir under intervjuns gång extrema i sina uttalanden, och några säger att skilsmässan, som normalt kan ses som en förbannelse, trots allt är en välsignelse i fråga om funderingar över det närsociala och emotionella livet. Utan skilsmässan hade de fortsatt att intressera sig endast för arbete och sport $i$ all evighet utan att upptäcka vilken energi som ligger förborgad i föräldrarelationen. De använder termer som ökad känslighet och förnuft om detta fenomen.

Vi kan nämna vissa speciella teman: Man får distans till sig själv, man blir bättre skickad att skilja ut sig själv från andra och kan därigenom se sina egna önskningar och behov i relation till mamman och barnen. Man blir mer reflekterande och man inser att vissa otäcka ting, som skilsmässa, inte till varje pris måste undvikas, men däremot hanteras på ett förutseende sätt. Dessa

7 Denna punkt stämmer också väl med tesen om "optimala frustrationer" som finns hos Piaget, Vygotsky och andra utvecklingspsykologer: All kognitiv utveckling kräver att beteendet blir "lagom"problematiskt ellerstimulerande gåtfullt. Då blir det medvetet och individen kan kognitivt arbeta fram en lösning. Liknande tankar finns också i Deweys pargmatism och i G. H. Meads socialpsykologi, som vi använder vad gäller identitetsbyggandet hos "våra fäder och barn. pappor anser sig ha blivit mognare och fått bättre bedömningsförmåga gällande mänskliga relationer och problem. De är i stor majoritet $i$ vårt material.

Ett märkligt förhållande är, att vad som justsagts om fäderna ocksågäller för barnen; det gäller dessutom både för tonåringarna och för vissa av de mer talföra yngre barnen. Många kan ge sig in i en diskussion; de kan berätta och fundera över temat. Barn reflekterar både ställföreträdande för pappan och för sin egen del. Därvid kan de se positiva sammanhang, som att de har fått nya famil jerelationer och syskon. Detta tema är frekvent hos de äldre, och ett par av de yngre tonårsbarnen ( 12 och 15 år) ger sig in i yviga och glada berättelser om sina nya syskon. Barnen framhäver också den goda känslan i att ha två verkliga hem.

Marcus t.ex., 12 år gammal, räknar in både moderns nye mans barn och pappans nya sambos barn i sin syskonkrets och blir alldeles uppsluppen av att konstatera att han har ca 25 syskon och nära släktningar i sin egen generation, trots att han är enda barnet till sin egen mamma och pappa. Hans äldsta syster är långt över 30 år och har egna barn. Allas våra skrattmuskler har blivit trötta när Marcus är färdig med sin berättelse och vi med våra kommentarer till den. Och Marcus själv tycks oss som ett lyckligt barn, trots att skilsmässan mellan hans egen mor och far var svår, och aldrig blev känslomässigt bearbetad.

\section{A 2: Koncentration på och engagemangibarnen}

Ett tema förefaller paradoxalt. Även detta handlar om de "lyckliga» följderna av skils- 
mässa, men relaterar mera direkt till umgänget fäder - barn. Några särskilt illustrativa uttalanden har vi om detta. En pappa säger att just när man är skild och inte träffar sina barn hela tiden kan man "träffa barnen mycket mer». Och en annan säger att "skilsmässan gör en till en bätttre förälder." Sådana uttalanden är förstås medvetet tillspetsade. Det finns ett budskap: När du är frånskild har du ett individuellt ansvar för barnen och deras välfärd. Om man inte får föräldrajobbet gjort ordentlig, så finns där ingen annan att klandra än sig själv. Detta visar sig som ett slags uppenbarelse för en del av fäderna, (vilket i och för sig kanske är mindre smickrande för deras föräldragärning före skilsmässan). Föräldraskapet är inte (längre) en automatisk affär. ${ }^{8}$ När man går är man inte medveten om att man gör det. Men när man snubblar och gången avbryts, blir man mycket medveten om att det var just gick som man gjorde nyss. Föräldraskapet fullbordas inte av att bara se barn födas och av att träda in i försörjarrollen. ${ }^{9}$ Att bli förälder innebär ett dagligt vävande av intima relationer vilkas intensiva

8 En del konventionell kunskap och forskning antyder att barnaavlandet (statistiskt) är ett mer genomtänkt existentiellt val för kvinnor än för män, som betraktar det mest som en självklar följd av sammanlevandet med kvinnan. Denna attityd har åter bekräftats i en ny studie av engelska och svenska familjer (Kearney et al., 2000).

9 Det konventionella porträttet av fadern som "bread-winner", som talas mycket om i den engelskspråkiga litteraturen (t.ex. Lewis \& O’Brien 1987) förkastas helt av våra fäder. Vissa av dem har svårt att tro oss när vi berättar om detta tema, utan tror att vi talar om mycket äldre tider. och känslomässiga karaktär många män inte inser klart i förväg; de kan behöva ett individuellt ansvar för och förhållande till barnen, för att blomma ut i denna kunskap. Flera fäder återvänder till talet om att umgänget blir mycket mera totalt, vilket ger en huvdsakligen god känsla, även om man också kan bli trött av detta intensiva sätt att vara förälder.

Den obligatoriska pappamånaden verkar i denna riktning. Vårt material kan stödja obligatoriet, därför att många av våra pappor talar just om sin tidigare omedvetenhet om föräldraskapet och om skilsmässan som en startpunkt för en ny och djupare medvetenhet. Möjligen kan obligatorisk pappamånad medverka till att dämpa utvecklingen av antalet skilsmässor genom att göra männen mer medvetna om relationsproblemen i familjen.

Ilitteraturen diskuteras en särskildaspekt av detta, som bekräftas i vår studie. En viktig identifikation för flickor är att vara den som bäst kan hantera relationerna $\mathrm{i}$ familjen (modern). Därför har en del kvinnor en tendens att dominera männen i detta avseende (Chodorow 1978, Haavind 1982). Männen å andra sidan är dåligt utrustade för att möta denna form av moderlig/ kvinnlig makt. De kan därför känna en lättnad och vara mer initiativrika när de lämnas ensamma med barnen. Spontana uttalanden i denna riktning är vanliga bland våra pappor. Flera av dem berättar om svårigheter innan de separerade att hävda sig mot mamman även i frågor där de haft en klar uppfattning. Hennes ideologiska övertag var för tydligt och starkt, och själva saknade de ett klart språk för att uttrycka vad de ville. $\mathrm{Nu}$ kan de agera mera självständigt. 
Den traditionella fadersrollen i industrisamhället avspeglade distans och passivitet i relation till barnen. Denna attityd förnekas explicit av våra pappor, och det är som om de redan befinner sig på större avstånd från denna modell än våra familjeteorier; de tar inte tanken på riktigt allvar. Motbilden levereras kanske bäst av barnen, som är mindre part i målet än fäderna; inget enda av barnen meddelar någon känsla av fadersdeprivation ${ }^{10}$. En del barn talar om ledsnad och saknad och ilska när pappa flyttade hemifrån, men detta gällde en kortare period, och det finns ingen permanent dålig känsla i samband med detta. Samtliga barn anser sig ha en pappa som är hängiven både dem själva och sin egen fadersidentitet. ${ }^{11}$ Barnen har för övrigt en motsvarighet till faderns "verkligen-rå-om-barnenukänsla. De anser sig leva med båda sina föräldrar i full utsträckning.

Detta kan jämföras med att många av våra pappor anser sig själva ha haft en pappa som varit påtagligt andligen frånvarande. Barnens rapport på denna punkt ska inte dölja deras känsla av välbefinnande när hela den ursprungliga familjen och släkt och vänner träffas vid särskilda tillfällen, som jul och

10 Modersdeprivation är den psykologiska facktermen. Man kan bilda en motsvarighet för det manliga könet. Den verkar självklar, men har av någon anledning inte blivit etablerad. Orsaken till detta kan vara intressant att studera.

11 De yngre barnen har oftast blivit intervjuade i faderns sällskap, men detta invaliderar inte helt resultaten ens för dessa intervjuer; vi har kunnat erfara den stämning som funnits mellan far och barn, det fenomen som populärt kallas "vibbaru. Detta finns med i vår samlade bedömning. födelsedagar. Några barn tillskriver pappan en speciell roll vid sådana tillfällen.

\section{A 3: Variation i livet för far ochbarn}

Det finns skäl att göra en särskild poäng av den positiva tendens som nyss rapporterats. Det finns en skenbar paradox i att villkoren runt skilsmässan kan göra relationen mellan far och barn mer intensiv, nära och varm men också mera varierad i fråga om fritidsprojekt som att hälsa pâ släktingar och vänner. Fäderna berättar också om att just kombinationen av intensitet och den intill utmattning höga kravnivån på närvaro ger en speciell varm karaktäråt relationen, trots alla nya konkreta ansvarigheter. Tiden blir fylld av olika aktiviteter, av vilka en del är projektorienterade, som att genomföra planerade utflykter, medan andra är mer meditativa, som att läsa långa kvällssagor, eller att bara finnas till i varandras närvaro.

Denna variation ger också eko på andra områden. Båda parter, men särskilt fäderna, utvecklar en mer finstämd analysförmåga gällande relationer. En och samma person kan inses ha olika egenskaper. Exhustrun ses som en person med både goda och onda drag. Pappornas egna fäder blir föremål för mycket mer intensiva reflexioner än förr, och de antar också både goda och dåliga drag. ${ }^{12}$ I vissa fall har umgänget med den egna fadern blivit intensivare än förr, vilket haft den lyckliga bieffekten att barnen har fătt mycket mera farfar (och därigenom farmor)

12 Det är påfallande att många av papporna från början har haft en negativ syn på sina egna pappor. 
efter skilsmässan. Kunskapen om de samhällsvillkor som omgärdat den egna faderns mer tafatta och distanta föräldraskap har djupnat. Likaså begrundas villkoren runt familjelivet på ett mer aktivt sätt än förr. Men kritik- och analysförmågan gällande t.ex. manlig jargong på jobbet tar ocksåstora steg framåt. En pappa berättar att han förr var lite negativt stämd mot invandrare, att skilsmässan emellertid gjort honom till en människointresserad "filosof", och att han därför numera intresserar sig starkt positivt för att lära sig om invandrares levnadsvanor. Den mer emotionellt laddade och ansvarsfyllda karaktären i umgänget med barnen resulterar $i$ en en avsevärt mer finstämd empati och analysförmåga rörande mänskligt socialt liv i allmänhet, och familjeliv i synnerhet.

Allt detta är i linie med Giddens' (1991 och 1992) teser om ökande reflexivitet $\mathrm{i}$ det senmoderna samhället, liksom också med Bauman (1991), som föreställer sig det postmoderna livet som ambivalent, tvetydigt och därför också som underkastat ett ständigt väljande av handlings- och levnads-typer. Dessa tankar understöds av vårt material, och av särskilt intresse är att även de små barnen utövar de nämnda tendenserna i viktiga avseenden. Giddens och Bauman hjälper oss att förstå den okonventionella och otraditionella karaktären $i$ vårt material, både vad gäller fäder och deras barn. Med utgångspunkt i traditionell familjeteori av både sociologiskt och psykologiskt slag hade vi väntat mer stereotypa attityder med bl.a. mycket mer av attityden skilsmässan-som-katastrof. ${ }^{13} \mathrm{Vi}$ fann i stället mogna

13 Den traditionella bilden bekräftas också i dagens amerikanska kultur i t.ex. en survey individer med djup reflexiv-sensitiv kapacitet hos båda parter.

Ett ytterligare fynd som låter sig tolkas i linje med Giddens och Bauman är att den reflexiva attityden är företrädd $i$ alla sociala strata. Även språket och dess bruk visar små variationer i fråga om socialgrupp. T.ex. en bagare med endast grundskola verbaliserar lika flödande och nyanserat som ingenjören, om än med något annorlunda ordval. Hans kod är heller inte begränsad på det sätt som Bernstein (1971/73) visar i sin forskning. Detta står i skarp kontrast mot data från traditionell familje- och klassforskning både i England och USA (Young and Willmott 1986, Chodorow 1978, m.fl.).

\section{A 4: Slut på grälandet; barnens reaktioner}

Tematiken kring skilsmässa som motsatsen till katastrof för barnen har en annan poäng attbelysa. Denkan också förståsi relation till socialpsykologisk identitetsteori. En olycklig relation mellan de två vuxna är det tyngsta som finns att bära, enligt barnen. Det är främst därför skilsmässan kan ses som en lättnad. Men närmare bestämt, varför då?

Små barn har inte en egen identitet att luta sig på i krissituationer. De vet bokstavligen inte vilka de är, och föräldrarna utgör det främsta medlet för dem att bli nnågon«. Det sker på minst två olika sätt. Barn bygger sig själva mycket konkret direkt från föräldrarna som råmaterial. De ser sig med föräldrarnas ögon. Denna process innefattar

över både vetenskapliga och populära fadersföreställningar (Lupton och Barclay 1997, särskilt kap. 3). 
"materialı från barnet självt; föräldern reagerar på barnets handlingar, och dessa reaktioner tas emot och bearbetas av barnet. Härigenom får barnet syn påsin egen gestalt, medierad genom föräldern. Men där finns också den andra processen, där barnet tar upp förälderns identitet: „Min pappa ser ut så här, och han gör dom här sakerna. Då ska jag göra som han gör, så blir jag lik honom! !14 Detta är den andra sidan av identitetskonstruktionen.

Om nu föräldrarna grälar sins emellan, så blir detta gräl till ett material för negativ identitetskonstruktion för barnet: det bygger upp sig självt på basis av ett gräl. Grälet blir inte bara ett yttre villkor, som det kan vara för föräldrarna själva, utan ett inre drag som bygger upp självet. Grälet blir på så vis värre i barnet än det är mellan föräldrarna, trots att barnet självt inte deltar. De kan ju klandra varandra, men barnet har ingen att ställa till svars. Grälet blir »internaliserat", som utvecklingspykologin benämner denna process: att leva är (delvis) att gräla. Det är därför som alla barnen med en mun säger att grälandets avslutning genom skilsmässan är något av det bästa som hänt. Därför är skilsmässan också en lättnad för barnen.

Barnen tillskriver inte någon förälder skulden för skilsmässan, så som de vuxna ofta gör gentemot varandra. De ser helt enkelt inte skilsmässa som något som över huvud taget implicerar skulden som feno-

14 Det mesta av allt detta sker givetvis omedvetet och på ett mycket subtilare sätt än jag sagt här. Jag har behandlat dessa processer på ett mer rättvisande sätt i t.ex. Berg (1992) och Berg och Johansson (1999). men. Skilsmässa kan vara något som hör till livet, som en del genomgår och andra inte, och detta är allt som behöver sägas, så länge som barnen fortsätter vara fria att träffa sina båda föräldrar på ett rimligt sätt. Den tunga och ibland infernaliska karaktären hos skilsmässan kan vara något som de vuxna tillskriver den, men de barn vi talat med gör det inte.

Skilsmässan i sig själv är alltså inte nödvändigtvis dålig för barnen, men förälderliga reaktioner kan vara det, särskilt när de grälar och skuldbelägger varandra. Detta kastar mer ljus på att dessa svenska skilsmässohistorier av idag ser så mycket mindre olyckliga ut än mycket som nämns i den internationella litteraturen. Möjligen har slutligen skilsmässa blivit ett mer "normalt" (= icke patologiskt) fenomen i samtidens Sverige, än det var i 70 - 90-talets USA och England. Möjligen är det därför som barnen inte är fadersdepriverade. ${ }^{15}$ Det betyder i så fall att faderns försvinnande från skilsmässofamiljen i första hand bör förstås och åtgärdas utifrån kulturella faktorer snarare än individualpsykologiska.

De enda olyckliga barn vi finner i vårt material är några få äldre barn som berättar om »dåligu skilsmässa för flera år sedan. Och vi noterar särskilt att den sorts gräl som avslutas endast därför att kombattanterna inte träffas längre, är sådant som dröjer kvar i barnets reaktioner som en olöst konflikt. Några av dessa barn vecklar in sig i psy-

15 Vi har också några historier från Föreningen Söndagsförälder, och bland dem finner vi att merparten har den infernaliska karaktären, som främst yttrar sig i att pappan av olika skäl saknar möjlighet att träffa barnen. 
kiska konflikter och motsägelser av typen att pappa/mamma är både ond och god i fråga om samma sak, att barnet tycker om och tycker illa om pappa av samma skäl osv.Sådana logiskasjälvmotsägelser börvara tungt gods att bära för vem som helst. En flicka på 19 år visar oss en djup förvirring och flera motsägelser i sin relation till pappan, trots att hon har ett regelbundet umgänge med honom.

Vi vill inte dölja kunskapen om att knapp ekonomi kan tillhöra det mest eländiga $i$ skilsmässan. Sådant rapporteras från flera länder. Särskilt tungt tycks problemet var i USA (Furstenberg \& Cherlin 1991) I vårt material spelar det emellertid en mindre roll, och bland barnen observeras dålig ekonomi över huvud taget inte alls. ${ }^{16}$

\section{B: \\ Den gode fadern; ett porträtt av den postmoderne engagerade pappan}

\section{B 1: Bortvittrade könsskillnader}

När vi ser på den förvirring i fråga om både faders- och mansroll som både vårt material och litteraturen uppvisar, så tycks det inte märkligt att våra pappor har diffusare uppfattningar om sig själva än deras barn har. Barnen undrar inte över vem pappa är, men pappa själv gör det. Detta tycks vara ett

16 En märkligt motsatt rapport kommer från Danmark (Christoffersen 1996) som menar att barn har det bättre hos pappan än hos mamman efter skilsmässa pga att pappan statistiskt sett har bättre ekonomi och vidare nätverk. fenomen som sträcker sig över åtminstone det moderna industrisamhället. „Fathers are not what they used to be. Fathers do not any longer model themselves on the image of the sovereign patriarch, the head of the family, who orders his wife and children around, but they have not developed a newidentity, either "(Lupton and Barclay 1999 p 14, min kurs). Barnen är inte betungade på samma sätt av köns- och föräldraroller, och de har kanske heller ingen stolthet investerad i saken, som deras fäder kan ha.

Fäderna säger sig nästan mangrannt inte ha någon kunskap om maskulinitet. Ett återkommande tema, när vi pressar på $\mathrm{i}$ intervjun, är att det inte är stora skillnader mellan man och kvinna, utan större skillnader mellan olika individer. Sedan är attityden "Det är ett helvete att vara man idag" näst vanligast. Endast två pappor uttrycker någon sympati för traditionella könsrollsskillnader, och då med starka reservationer och med distans. Den ende som har verklig substans i sin uppfattning om att det finns viktiga skillnader mellan män och kvinnor är den som hävdar att språket har olika användning och betydelse för könen. Språket är t.o.m. en barriär mellan dem.

Av särskilt intressse är att ingen enda säger att det finns klara skillnader mellan könen vad gäller omvårdnad och attityder mot barn. Fäder gör och tycker med rätta liknande saker som mödrar. Även här gör sig de individuella skillnaderna starka. Individualismen som kulturell form tycks har gjort sitt definitiva inträde även i uppfattningar om familjen ända därhän att könskulturen tynar bort. Skillnader mellan mor och far ses inte som skillnader mellan könen utan som individuella särdrag. Detta har teore- 
tiskt förutskickats länge (H Holter 1978) men har inte iakttagits empiriskt på ett systematiskt sätt. Dock nämns det i familjesammanhang av t.ex. Aarseth och Ö G Holter (1993) ett par år före vår studie. De använder begreppet androgynisering för utjämnandet av könsskillnader i kulturen.

Dessa teman tas upp också av barnen. Men igen: Fäderna gör sig problem av detta, medan barnen tar det som självklarheter utan problem. De har svårt att finna skillnader i beteende mellan mamma och pappa, men detta är helt i sin ordning. Och de känner inget behov av att bli behandlade på olika sätt av de två föräldrarna, antingen de är skilda eller inte. När barnen talar om hur deras pappor verkligen beter sig i vardagen, så finns en liten skillnad i riktning mot den traditionella uppdelningen mellan en projektorienterad pappa och en mer passiv bara-vara-orienterad mamma. Men detta är inget problem och det görs ingen poäng av det.

\section{B 2: Fädernas idealpappa}

Vi fortsätter denna rundvandring bland attityder till fadrandet i dagens svenska familjekultur (med den begränsning som självklart följer av vårt materials beskaffenhet) med en sorts rangordning, given av fäderna och deras barn. Vilka drag hos en pappa är mest uppskattade av fäderna själva, och hur upptas detta av barnen? Vi har gått närmare igenom de berättelser och bilder av idealpappan och den faktiska pappan som vi fått, och har kunnat göra en rangordning av drag som nämns. (Siffror indikerar frekvens för ett visst drag som explicit nämns av fäderna, men de visar inget av uttalan- denas eftertryck. Detta lämnas åt vår egen bedömning. Siffrorna uttalar givetvis ingen statistisk signifikans.)

Antalet röster för att en god pappa ska vara en modell eller ett mönster för sina barn är, inte överraskande, högt (11). Men när vi lyssnar till tonen i dessa röster, finner vi en grad av ytlighet eller pliktskyldighet $i$ vad som sägs. Det är något som sägs först, medan man funderar på vad som verkligen behöver sägas. Rösten ges med låg intensitet och med en touche av vaneprat.

Härnäst kommer engagemang och förmåga att vara ett stöd (10). Här nämns också viljan att vara närvarande för barnet på ett konkret sätt. (Alltså en skarp kontrast mot vad fäderna uppfattar för sina egna fäders faktiska beteende.) Detta tema blir strax ett ämne för intensivt och nyanserat pratande. Respondenterna tycker om att prata om detta, och de ger många exempel.

Denna karaktär av emotionellt engagemang i samvaron växer sig ännu intensivare $i$ en aspekt som vi kan kalla kommunikativitet (9). Särskilt fäderna omhuldar en föreställning om emotionell och rak kommunikation som samtidigt något av det mest behövda och saknade mellan föräldrar och barn idag. Vissa fäder blir starkt påverkade av detta ämne, en av dem därhän att han börjar gråta inför våra ögon när han talar om ensamma barn och dåliga kommunikationsvillkor i dagens samhälle.

Näst i ordningen har vi stabilitet och stadighet (7). Det är lätt att traditionellt tänka på detta som en skillnad mellan män och kvinnor. Men i vårt material tänker ingen att fäder är stabilare än mödrar är och ska vara. Det är en dygd som ska vara gemensam för föräldrarna. Attityden har att göra med det 
generella kravet på föräldrar att på ett klart sätt visa barnen hur världen är beskaffad.

I själva verket kan denna punkt ses som en summering av tre drag som följer härnäst i rangordning (med 6 röster vardera), nämligen vardagsengagemang, gränssättande för rätt sätt att bete sig socialt som en viktig del av uppfostran och slutligen att visa barnen den yttre världen och männens värld.

Temat kring faderns kulturellt nya kapacitet att ha drag av direkt och synlig emotionalitet och känslighet kommer härnäst, tillsammans med det besläktade draget att kunna vara en god lekkamrat. Det senare är väl känt i den psykologiska litteraturen rörande faderns roll, men används sällan i relation till emotionalitet. Det brukar stå som en motpol till moderns mer vårdande och mindre lekfulla attityd. Vi tror att det är signifikativt att lek och emotionalitet ofta nämns tillsammans bland dessa fäder. De två är besläktade. Leken antas av papporna innehålla en nödvändig dimension av emotionalitet, och papporna menar att män kan och bör odla denna förmåga.

Härnäst kommer så något som kallas »att vara sig själv«(4). Detta tycks i förstone vara en ren schablon: naturligtvis ska folk vara sig själva, vem annars och varför? Men en närmare titt avslöjar att det finns en speciell, delvis gömd och omedveten betoning på temat. Fäderna menar att i den traditionella familjekulturen finns det en press på fäder att inte vara sig själva. En pappa ska konformera med ett generellt manligt mönster som gör honom till en stereotyp. Därigenom visar han sig inte i full längd som pappa till just sitt eget barn. Eller: Den enskilda pappans individualitet göms bakom mönster som generaliserar fadersgestalten till en avindividu- aliserad schablon på ett annat sätt än motsvarande förväntningar för modern innebär. Pappa spelar fotboll som andra pappor med barnen, medan mamma ägnar sig åt personligt umgänge med sitt barn. På detta sätt watt vara sig själv« - uttrycker fäderna därför ett stöd för vad de uppfattar som en emancipatorisk process i omvandlingen av mansoch fadersrollen. Tolkat så försvinner den ytliga karaktären $\mathrm{i}$ »att vara sig själv».

Ett fåtal fäder säger oss att en god far ska vara en god kamrat eller kompis (3). För merparten är detta emellertid ett diskutabelt drag . Flera tar upp tanken i kritiska termer: att vara kamrat är att frånsvära sig det fostraransvar som ligger i föräldrarollen. Därför ska en god far absolut inte försöka framställa sig som en kompis. Det finns ett socialpsykologiskt sinnelag med i bilden här. En pappa kan och bör vara lekkamrat, men detta gäller inom en i tid och rum avgränsad zon. ${ }^{17}$ När leken är över återinträder fostraransvaret. Detta innebär både att vara den som bestämmer och den som ska tjäna som stöd och hjälp, två komplementära och olika funktioner som båda ligger klart utanför lekkamratens rollgestalt.

En smula förvånande är det att endast två fäder av sig själva nämner att en god far bör visa sin dotter hur en god och konstruktiv manlighet ser ut. Just detta är ju ett tema i många psykologiska doktriner av både mera populärt och mera vetenskapligt svårtillgängligt slag, av vilka vissa är härledda från freudsk och lacaniansk psyko-

17 Jag hänvisar också till Johan Huizingas lekteori (1955) även utan att någon pappa gör det. Hos Huizinga är just avgränsningen i tid och rum en konstituerande viktig aspekt av konceptionen av leken som mänsklig verksamhet. 
analys. Men våra pappor har inte mycket till övers för sådana teorier. För det första är hela frågan inte särskilt intressant i relationen mellan föräldrar och barn, därför att hela vår kultur myllrar av schabloner kring könsvariabeln. Det finns faktiskt inget behov av att visa fram den goda maskuliniteten, för det finns så många bilder redan, som man inte kan konkurrera med! För det andra, och kanske viktigare: Denna fråga är inte något som är begränsad till bara fadern i relation till dottern utan ska bearbetas av båda föräldrarna. Mödrar ska vara goda gender-modeller för barn av båda könen, och det ska också fäder vara. Och det finns ingen skillnad mellan könen vad gäller detta ansvar. Mödrar kan och ska vara modeller på samma sätt som fäder, och de kan visa modeller för gott faderskap, liksom fäder kan visa modeller för gott mödraskap och kvinnlighet.

Tematiken kring skillnaderna mellan man och kvinna daterar sig i modern tappning åtminstone tillbaka till Simone de Beauvoir (1986). Hon etablerar vad som numera kallas en konstruktionistisk ståndpunkt när hon menar att man inte är kvinna utan blir det, och att att det inte finns någon skillnad mellan könen, utan att en sådan görs. Hennes ståndpunkt är grund för den som Judith Butler och de moderna konstruktionisterna har utvecklat så intensivt. Det intressanta för oss är att våra pappor (och barn) utan akademisk lärdom tycks ha tagit den konstruktionistiska ståndpunkten helt och hållet till sig som en självklarhet, även i de ganska många fall där en starkt reflekterande diskussion förekommer.

Det är en postmodern uppfattning fäderna har i dessa frågor. Den mångfald av värderingar, den avsaknad av enkla kategorier och schabloner och den svårighet att träffa enkla beslut i livet, som Bauman och andra teoretiker beskriver, är för våra pappor ett självklart livsvillkor, som de förhåller sig aktivt gentemot.

Ett sista drag vi ska nämna är en särskilt referens till ansvarighet, och den man som säger detta menar att det finns ett särskilt ansvar för fadern att visa på reciprociteten i mänskliga relationer; en far ska visa sina barn hur det är att ta och ge ansvar gentemot andra människor.

Listan hittills ger en överflödande bild av faderligt ansvar. Faktiskt är det endast punkten "lekkamrat" som inte klart implicerar faderligt ansvar, och i detta fall, där det är tre unga fäder som talat, säger de alla tre också att en god fader inte kan nöja sig med att vara en kamrat. Praktiskt taget alla övriga drag hos den gode fadern implicerar ansvarighet på ett eller annat sätt.

Det finns en stereotyp om att fäder är och ska vara mer "instrumentella" och praktiskt orienterade än mödrar (jfr Chodorow a.a.). Fäder spelar fotboll hellre än att läsa sagor, de tar med sig barnen ut i världen mer än att prata med dem om relationer mellan människor. Det är intressant att finna att varken fäder eller barn ger så mycket uppmärksamhet åt sådana opinioner. Ändå är det så att projekt som att hälsa på släkten eller gå på matchen är en vanlig och uppskattad verksamhet. Det är bara det att det görs utan att fundera på det som någonting annorlunda än vad mamma skulle göra med barnen. 


\section{B 3: Barnens idealpappa}

Det ska sägas igen, att ovanstående rangordnade lista huvudsakligen härstammar från fadersintervjuerna; dessa är mycket mer flödiga än barnens, men där de senare kunnat hjälpa till har de fått komma till tals. De punkter man mest kommer ihåg från barnen är att pappor och mammor inte beter sig eller bör bete sig särskilt olika, att detta gäller både den faktiska pappa-mammarelationen och i ännu högre grad idealbilden, samt att pappor måste finnas till på ett konkret sätt för barnen, inte bara som en rollfigur i bakgrunden. Vi finner också att barnen anser sig ha en tät relation med sin pappa. Faktiskt är det så att flera anser sig ha idealpappan i sin egen far. Flera barn vill träffa pappa mer, men är nöjda med honom på alla sätt. Inga barn meddelar något annat, ${ }^{10}$ men vi har inte tailat med ailia barn. Bland dem vi inte talat med har vi tre stycken med pappor som inte anser sig ha tillräckligt mycket kontakt med sina barn (i alla tre fallen beroende på svåra samarbetsproblem med mamman).

Det kan vara på sin plats med en sammanfattning av barnens svar på den direkta frågan om hur idealpappan ser ut, en fråga som vi ställt sist i raden av frågor som berört barnets relation till den egna pappan. Följande begrepp nämns som viktigast: En pappa ska lyssna, han ska vara närvarande, och han ska göra roliga saker med sina barn. De två första av dessa är bland de högst ran-

18 Detta hindrar dock inte att några få av de äldre barnen kan vara kärleksfullt kritiska, och att ett uttrycker ett visst missnöje. Det är samma flicka jag tidigare nämnt som vecklar in sig i motsägelser. kade av fäderna själva och den sista nämns explicit av flera av dem, även om den inte håller högsta position för vare sig frekvens eller intensitet.

I vissa fall med endast två-tre dagar umgänge per två veckor har vi särskilt frågat om just de snåla temporala villkoren. Det blir då tydligt att båda parter uttrycker klart högre värdering av kvalitet än av kvantitet. Eller: Mycket bättre att ha en lycklig pappa (och lyckliga barn) en kortare tid, än att ha en olycklig och stressad pappa varje dag. ${ }^{19}$ Det är ju faktiskt barnen som uttrycker detta klarast: Det är de som tydligast försvarar möjligheten till skilsmässa. Även vad gäller direkt otrohet menar de att fadern (eller modern, ty hos barnen finns ingen könsdiskriminering!), när han/hon blir kär i en annan person än den andra föräldern, ska ha rättigheten att leva med den nya partnern. Och vissa barn drar uttryckligen ett kausalt samband mellan den nya kärleken och den lyckligare fadern, som då anses vara en mer intensivt närvarande pappa, så fort han har chansen.

Det finns, som enda uttryckta missnöje, denna återkommande punkt om att träffa pappa mera. Den är särskilt vanlig bland de yngre barnen, och den är reciprok på ett helt harmoniskt sätt. Just de barn som uttrycker den starkast har fäder som också uttrycker den starkt. (Vad de barn vi inte

19 Vissa undersökningar i Sverige (t.ex. Westin 1979) har givit vid handen att barn vill ha mer tid med föräldrarna hellre än fler och finare leksaker. Våra data stämmer till en kvalitativ analys av sådana data. De kanske inte bör tolkas kvantitativt; barnen menar att de vill ha meningsfull tid med föräldrarna, fast de uttrycker saken som om den gällde kvantitet av tid. 
talat med skulle säga, vet vi inte.) Barnen klandrar dock inte pappan. De har en realistisk kännedom om de snåla villkor som gäller för arbetande fäder och mödrar.

\section{Avslutning}

Min text började med syftet att studera den verkliga och önskade relationen mellan fäder och barn. Utgångspunkten har varit den kvantitativt missgynnade relation som föreligger i skilsmässofamiljer där fadern har flyttat hemifrån. Just genom detta tillvägagångssätt har vi landat på den punkt där vi finner väsendet hos denna relation. Just genom tidsbristen kommer båda parter att bättre känna vilka möjligheter som verkligen finns och vad de faktiskt önskar av varandra; de fader-barn-relationer vi har studerat har mognat i en process av socio-emotionell kompetens och en därmed djupare känslomässig förståelse av de krafter som är verksamma i intima familjerelationer. Denna mognad tycks vara jämnt fördelad mellan far och barn. Den har också haft ett högt pris. Dock är det att märka att priset för barnens del verkar vara mycket högre i fall där föräldrar inte har kunnat lösa sina emotionella konflikter utan dessa kvarstått olösta under åren. Dessa barn kan ha den olösta motsättningen kvar levande i sig.

Man brukar säga: Smakar det, så kostar det. Vi kan vända på talesättet och gå ett steg längre i tiden än talesättet inbjuder till genom att se hur tillvaron gestaltar sig när kostnaden har gjort sin smärtsamma verkan: Kostar det, så smakar det, men endast om förhållandena tillåter en tillfredsställande kognitiv och emotionell bearbetning, som bereder väg för mognad. Den emotionella kostnaden tycks kunna förädlas till en kvalitativ vinst i fråga om livsvisdom, som finner sin väg inte bara till fäder och tonåringar, utan även till yngre barn.

\section{Litteratur}

Bauman Z (1991) Modernity and Ambivalence. Oxford, Polity Press.

Bernstein B (1971/1973) Class, Codes and Control. London, Routledge and Kegan Paul.

Berg L-E and Johansson Th (1999) Den andre föräldern. Stockholm, Carlssons bokförlag.

Berg L-E och Chronholm (2001) Faderskap i förändring. Arbetspapper inom pågående forskningsprojekt finansierat av HSFR.

Blomqvist B (2001) Förskolebarnets relation till sin familj. Förändrandeförutsättningar och föreställningar 1950-1990. Department of Sociology. Göteborg studies in Sociology, nr. 4.

Burgess A (1997) Reclaiming Fatherhood. The Making of the Modern Father. London, Vermillion.
Butler J (1990) Gender Trouble: Feminism and the Subversion of Idenitity. New York, Routledge.

Chodorow N(1978/1995) The Reproduction of Mothering. Berkely, California University Press.

Christoffersen M N (1996) Opvekst hos faedre. Köbenhavn, The Danish National Institute of Social Research, report 96:23.

de Beauvoir S (1986) (4:e uppl) Det andra könet. Stockholm, AWE/Gebers.

Dinnerstein D (1976/1980) The Mermaid and the Minotaurus. NewYork, Harper \& Row Publications.

Faludi,S(2001) Ställd; omfärräderiet mot mannen. Stockholm, Ordfront.

Fost D (1996) The lost art of Fatherhood. American Demographics 18 (3). 
FürstenbergF and Cherlin A 1991 Divided Families. Cambridge, Mass. Harvard University Press.

Giddens A (1990) The Consequences of Modernity. Cambridge, Polity Press/Blackwell.

- (1991) Modernity and Self Identity. Cambridge, Polity Press.

- (1992) The Transformations of Intimacy. Cambridge, Polity Press.

Haavind H (1982) Liten og stor. Oslo, Universitetsforlaget.

Hagström Charlotte (1999) Man blir pappa. Föräldraskap och maskulinitet i förändring. Nordic Academic Press.

Holter H (1978) Familjen i klassamhället. Stockholm, Aldus.

Holter Ö Go Aarseth, H(1993) Mäns livssammanhang. Stockholm, Bonniers.

Huizinga J (1955) Homo Ludens; a Study of the Play Element in Culture. Boston, the Beacon Press.

Kearney, Manson \& Plantin (2000) Fatherhood and masculinity; University of Sunderland, England, Center for Social Research and Practice.

Lamb, M. ed. (1997) The Role of the Father in Child Denelopment. New Vork, Ni: Niley a Sons.

Lasch Chr (1977/1983) Den belägrade familjen. Stockholm, Norstedts

- 1979 The Culture of Narcissism. New York. Warner Books.

Lund M (1987), article in Lewis, C \& O'Brien M (1987) Reassessing fatherhood. London, SAGE. Lupton D and Barclay L(1997) ConstructingFather- hood. London, SAGE.

McLanahan S and Sandefur G (1994) Growing up with a Single Parent. Cambridge Mass. Harvard University Press.

Plantin L(2001) Mäns föräldraskap; Om mäns upplevelser och erfarenheter av faderskapet. Göteborgs University. Department of Social Work.

Pleck J H(1997)Paternal Involvement:Levels, Sources and Consequences. In Lamb, M. ed. 1997 The Role of the Father in Child Development. New York, Wiley o Sons.

Pleck J H, Lamb M E, \&Levine J A (1986). Epilogue: Facilitating Future Change in Men's Family Roles. In Lewis R. A. \& Sussman M (Eds) Mens's Changing roles in the Family. New York. Haworth

Spock B (1946/1968)Baby and Child Care. Pocket Books, New York.

Wallerstein J and Kelly J (1980) Surviving the Breakup. London, Grant o McIntyre.

Westin Ch(1979) De besvikna; en studie överbarns uppsatser, och en undersökningiemotionensfenomenologi. Göteborg, Bokförlaget Korpen

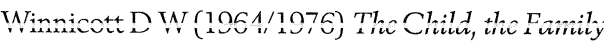
and the Outside World. Harmondsworth, Penguin.

- (1981) Lek och verklighet. Stockholm, Natur och Kultur.

Young and Willmott (1957/1986) Family and Kinship in East London. Harmondsworth, Penguin.

\section{Summary \\ Good enough fathering On identity formation in divorced fathers and their children}

Research on divorce is often research on misery. There is, however, another side. The article brings some positive aspects of fathering under conditions of divorce into the limelight, using interviews with divorced fathers and their children. The sample is characterized by highly motivated fathers, striving to maintain parenthood in spite of divorce. The questions picked out are the ones concerning the actual doings in everyday life between the respondents, with both sides being interviewed. But the picture of 
the ideal father is also scrutinized in its different aspects. The resulting picture supports a postmodern conception of parenthood, where the difference between the sexes is diminished in all social classes, whereas individual differences are stressed. Divorce as such is accepted, more readily among children than among their fathers. However, one aspect seems unbearable to children: bad and/or hostile communication between parents. Remaining parental conflicts make the children's story inconsistent and contradictory. The conclusion is that children have a worse time solving parental conflict than parents themselves have. These results are interpreted according to social psychological theory. 